\title{
Olga Kawczyńska
}

\author{
Uniwersytet Łódzki
}

\section{Świat bez demokracji. Ideologiczne i polityczne założenia systemu politycznego Korei Północnej.}

Współczesna Korea Północna jest jedynym państwem o charakterze totalitarnym. W sytuacji, gdy większość państw przeszło transformację systemową KRLD pozostaje "niezdobytym bastionem", w którym mimo konstytucyjnych gwarancji demokratyczne zasady nie są wdrażane.

Demokracja to ustrój cechujący się suwerennością narodu, poszanowaniem praw mniejszości, trójpodziałem władzy, szeroko rozumianym pluralizmem, konstytucjonalizmem, a także odbywającymi się cyklicznie wyborami i kadencyjnością władz. Analizując konstytucję Korei Północnej wydaje się, iż część z tych założeń powinna być realizowana. W ustawie zagwarantowana jest silna pozycja ludu w procesie decyzyjnym, a także wolności obywatela, możliwość rozwoju, głoszenie idei, swoboda religijna etc. Praktyka polityczna, jak zostanie wykazane poniżej, znacząco odbiega jednak od zapisów konstytucyjnych. 
Koreański totalitaryzm opiera się na ideologii wodzostwa i stałych elitach władzy, w szczególności Wodzu.

W 1948 r. władzę w Koreańskiej Republice LudowoDemokratycznej objął Kim Ir Sen, który uczestniczył w wojnie w Mandżurii, gdzie był uznany przez Japończyków za jednego z najgroźniejszych przywódców ruchu oporu. Jego zasługi stopniowo obrosły w kult, który stale się rozwijał. Przez obywateli uznawany był za syna narodu, bohatera, wyzwoliciela. Wierzyli, że „nie ma większej powinności aniżeli służyć mu absolutnie i bezwarunkowo"1. Formalnie został premierem KRL-D i sekretarzem generalnym rządzącej Komunistycznej Partii Pracy Korei, która powstała w wyniku fuzji Koreańskiej Partii Komunistycznej i Północnokoreańskiej Partii Robotniczej, a tytuł prezydenta przyznał sobie dopiero w $1972 \mathrm{r}$.

W latach 40. wizja Kima była bardziej rewolucyjnonacjonalistyczna niż demokratyczna i w tym czasie powstała idea „dżucze”2, choć sam termin pojawił się dopiero w 1955 r. w przemówieniu wygłaszanym przez „Wielkiego przywódcę”, który powiedział: „Ideologia dżucze w kilku słowach oznacza, że twórcami rewolucji są ludzkie masy"3. Koncepcja ta zakłada, iż system składa się z:

1. Samowystarczalnej gospodarki, opartej o system centralnego planowania, która pozwala zabezpieczyć kraj przed wpływami narodów

${ }^{1}$ T. Goban-Klas, Korea. Historia i współczesność. Od pustelniczego królestwa do azjatyckiego tygrysa, Toruń 2006, s. 157-175.

${ }^{2}$ www1.korea-np.co.jp/pk/062nd_issue/98092410.htm.

${ }^{3}$ www.krld.pl/krld/juche, 19.12.2011. 
imperialistycznych oraz zapobiec kryzysowi ekonomicznemu i zagranicznym wpływom - umożliwia wyeliminowanie różnic klasowych i rozkwit narodu.

2. Niezależności politycznej i ideologicznej. W zakresie obronności podstawową rolę odgrywa armia, której zadaniem jest obrona osiągnięć rewolucji przed agresywnym amerykańskim imperializmem.

3. Niezniszczalnej więzi między ludzkimi masami i Wodzem, co oznacza „możliwość zbudowania niezależności i suwerenności, gdzie ludzie mogą używać swoich talentów i siły dla wspólnego dobra"4.

4. Centralną pozycję człowieka w rozważaniach teoretycznych: „człowiek jest gospodarzem wszystkiego i on decyduje o wszystkim"5.

5. Odejście od marksizmu, który za nadrzędne zadanie stawia filozoficzną analizę istoty świata materialnego i ogólnych prawidłowości jego ruchu, ponieważ północnokoreańska filozofia skupia się na wyjaśnianiu istotnych właściwości człowieka oraz prawidłowości właściwych ruchowi ludzi- jako społecznej formie ruchu6.

6. Eksponowanie wyjątkowości narodu północnokoreańskiego, którego niezbędnym spoiwem jest Wielki Wódz.

7. Idealizowanie warunków rozwojowych Koreańczyków i motywowała ich ubóstwo ascetycznym

\footnotetext{
${ }^{4}$ Ibidem.

${ }^{5}$ www.krld.pl/krld/biblio/kimdzongil/dzuczesamoistna.pdf

${ }^{6}$ Yonhap News Agency, North Korea Handbook, Seul 2003 r.
} 
stylem życia, który świadczy o wyjątkowości państwa i wspiera mocarstwowe aspiracje.

8. Kult Kim Ir Sena, tzw. kimirsenizm, ukazujący zaprawionego w bojach bohatera, któremu niestraszne są wszelkie przeciwności losu i efektywnie dąży do osiągnięcia globalnej dominacji KRL-D, która jednak wiąże się z wieloma wyrzeczeniami ze strony społeczeństwa7. Koncepcja dżucze uzasadnia sukcesję władzy Kimów głosząc, iż istota świata polega na tym, że jest on rządzony i przeobrażany przez człowieka, czyli aby osiągnąć sukces władzę powinna dzierżyć silna jednostka.

9. Długofalowym celem Kima było także zjednoczenie z Koreą Południową ${ }^{8}$.

System koreański opiera się na silnym przywództwie. Fundamentem funkcjonowania KRL-D i całkowitej zależności mas, jest „teoria wodza”, która głosi, że to nie poszczególne klasy społeczne, masy ludowe, narody czy rewolucyjne partie mają wpływ na rozwój ludzkości, ale wyłącznie wódz i jego wola. Wybitna jednostka nadaje kierunek działania, wskazuje drogę, tworzy ideę i staje się gwarantem zwycięstwa. Wódz znajduje się w samym centrum mas, rozumie ich potrzeby, pragnienia i w pełni je zaspokaja. Wyjątkowe kwalifikacje władcy i powszechna miłość, jaką darzą go ludzie, wyraża

${ }^{7}$ M. Warner, A Historical-Critical Examination of the Evolution of North Korea's Juche Ideology Using Fantasy Theme Analysis: A Vision Transformed, 2008, s. 12-17.

${ }_{8}$ M. Lasoń, Wojna Koreańska, [w:] E. Cziomer (red.), Międzynarodowe stosunki polityczne, Kraków 2008, s. 204-208; Han S. Park, North Korea: ideology, politics, economy, Prentice Hall 1996, s. 10-12. 
doskonale spełnienie ideałów demokratycznych. Jak twierdził Kim Dzong Il, „uświadomiwszy sobie głęboko, że najpiękniejsze i najowocniejsze życie polega na tym, aby uważając zawsze wodza za niezachwianą ostoję w duszy, wiernie wykonywać wytyczone przez niego zadania rewolucyjne, powinniśmy przejawiać swą bezgraniczną wierność wobec niego w toku działalności rewolucyjnej zmierzającej do urzeczywistnienia jego idei i woli"9. Takie założenia prowadzą do całkowitego podporządkowania i izolacji społecznej.

Gdy w 1994 r. Kim Ir Sen zmarł przyznano mu tytuł „Wieczny Prezydent”, a termin ten funkcjonuje do dziś. Władzę przejął jego syn, Kim Dzong Il”10. W 1997 r. formalnie został sekretarzem generalnym Partii Pracy Korei i przewodniczącym Narodowej Komisji Obrony, która jest jednym z najważniejszych organów w państwie. Kim był propagatorem doktryny „songun,” polegającej na podkreśleniu priorytetowej roli Koreańskiej Armii Ludowej w życiu politycznym, a co za

${ }^{9}$ Kim Dzong Il, 0 ideach dżucze naszej partii, Phenian 1988, s. 27.

${ }^{10}$ Kim Dzong Il już od 1991 r. stopniowo obejmował wyższe funkcje w Koreańskiej Armii Ludowej. Został naczelnym dowódcą KAL, następnie w kwietniu 1992 r. marszałkiem, a 8 kwietnia 1993 r. zajął stanowisko przewodniczącego Komitetu Obrony KRL-D. W dniu śmierci ojca sprawował kontrolę nad wszystkimi segmentami władzy w armii, co znalazło odzwierciedlenie w wymianie „starych” dowódców wojskowych na pokolenie ludzi z nowego „zaciągu kimdzongilowskiego W latach 1992-1998 nominacje generalskie otrzymało aż sześciuset oficerów, a liczba wicemarszałków w 2003 r. wzrosła do 15. Armia nie potrzebuje tak wielu marszałków, generałów i pułkowników, więc awanse tego okresu mają czysto polityczne podłoże. Kim Dzong Il wynagradzał armię za wyniesienie i utrzymanie go na szczycie władzy. J.Bayer, W. J. Dziak, Korea \& Chiny. Przyjaźń i współpraca, rywalizacja i konflikty. Tom 1. Strategia i polityka, Warszawa 2006, s. 295. 


\section{4 | Olga Kawczyńska}

tym idzie przeznaczaniu na nią znacznych środków z budżetu państwa. Słowo „songun” oznacza prawość, uczciwość, prawdę, a także chwałę. W praktyce stanowiła ona uzasadnienie dla militaryzacji wszystkich aspektów życia społecznego w kraju i uzasadnia ideologicznie „rodzinną” sukcesję władzy. Uznawana była jednocześnie za strategię, doktrynę, teorię i filozofię, ale przede wszystkim oryginalną, niepodważalną myśl głównodowodzącego Kim Dzong Ila11: „Songun to znaczy wzmacniać własne siły rewolucyjne, pewnie bronić Ojczyzny, usilnie posuwać naprzód budownictwo socjalistyczne, oddając $w$ działalności państwowej pierwszeństwo kwestii militarnej i czyniąc Koreańskq Armię Ludowa głównym oddziałem rewolucji"12. W zamyśle autorów propagowana idea miała być realną alternatywą polityczną wobec pojawiających się postulatów otwarcia i reform, oznaczającą postępującą militaryzację z wizją przekształcenia państwa w „niezdobyty bastion”, zdolny przeciwstawić się wszelkim zagrożeniom, zarówno zewnętrznym jak i wewnętrznym. KAL ma obecnie wielką i realną władzę, prestiż, honor, przywileje oraz poszanowanie i autorytet w społeczeństwie ${ }^{13}, 14$.

${ }^{11}$ Suk H. Kim,T. Roehrig, B. Seliger, The Survival of North Korea: Essays on Strategy, Economics and International Relations, 2011, s. 34.

12 J. Bayer, W. J. Dziak, op. cit., s. 299.

${ }^{13}$ Kyung-Ae Park, S. Snyder, North Korea in Transition. Politics, economy, and society, USA 2013, s. 11-13.

${ }^{14}$ Korea jest najbardziej zmilitaryzowanym państwem na świecie, 419 żołnierzy na tysiąc obywateli. Liczebność armii wynosi $1,1 \mathrm{mln}$ (czwarte miejsce na świecie). Siły Koreańskiej Armii Ludowej posiadają rozbudowaną liczbę instalacji wojskowych rozsianych po całym kraju, liczne fabryki amunicji oraz zwarty system obrony przeciwlotniczej. 
Ideologia dżucze stawia w centrum uwagi zawsze „aktywnego człowieka”, co jest charakterystyczne dla systemów totalitarnych. Jednostka postępująca wedle wskazań dżucze powinna mieć gospodarskie, aktywne podejście do spraw ekonomicznych i politycznych oraz zajmować twórcze i samodzielne stanowisko w przeobrażaniu przyrody i społeczeństwa. Samodzielność człowieka, jest jednym z podstawowych aksjomatów „filozofii dżucze”. Wieczny Prezydent twierdził: „Jeżeli człowiek utraci samodzielność, to już nie można nazwać go człowiekiem, nie będzie się różnił od zwierzęcia”15. „Podstawa socjalizmu to lud. Nasza polityka stawiająca interesy ludu na pierwszy plan, to prawdziwie socjalistyczna polityka, polityka bezgranicznej miłości i zaufania, szlachetna o wysokiej moralności polityka. Cała linia, polityki naszej partii $i$ władz Republiki odzwierciedlajq̨ wolę i żq̨dania mas ludowych, pomyślnie wcielane sq one $w$ życie ze świadomym entuzjazmem i z walkq mas ludowych. W naszym kraju wzrost dobrobytu ludności zalicza się do najwyższych pryncypiów działalności partii i państwa, hasło 'służę ludowi!' całkowicie ucieleśnia się $w$ działalności państwowej"16. Jest on gospodarzem świata,

Posiadają również trzeci co do wielkości arsenał broni biologicznej na świecie. Największym atutem KAL są oddziały sił specjalnych w liczbie 180 tysięcy. Stawiają one Koreę Północną na trzecim miejscu pod względem liczebności oddziałów elitarnych wśród wszystkich światowych armii. Zob. www.krld.pl/krld/biblio/kimdzongil/oumocnieniu.pdf.

${ }^{15}$ Kim Ir Sen, Osiagnijmy wielkie zespolenie naszego narodu, Warszawa 1992, s. 5.

16 www.krld.pl/krld/biblio/kimdzongil/krldniezniszczalne.pdf, (dostęp: 24.04.2012). 
który rozwija się wyłącznie dzięki człowiekowi poznającemu, ujarzmiającemu i przeobrażającemu go. Z założeń doktryny wynika również, że człowiek sam może decydować o swoim losie ${ }^{17}$.

Istnieje przekonanie, że „lud jest wiecznym dzieckiem”, Partia Pracy jest partią-matką, która dba i troszczy się o swoje kochane dzieci i musi wziąć odpowiedzialność za los ludzi, stale ich pilnując i stając się prawdziwym przewodnikiem i opiekunem mas. Pogląd ten motywuje obawy człowieka związane $\mathrm{z}$ opuszczeniem sfery bezpieczeństwa (rodziny), utrzymując go w więzach reżimu i organizmu partyjnego.

W Korei Północnej obecna jest także teoria rasowa, która podkreśla, że obywatele prezentują „szczytne zasady moralne”, są „homogeniczni, w związku z czym łączy ich silna miłość braterska”, oraz przekonanie, że „nasz lud jest[...] najszlachetniejszy i najczystszy na świecie”18. Małżeństwa mieszane są niedopuszczalne, ze względu na możliwość skażenia idealnej rasy.

Propaganda KRL-D żywi szczególną niechęć do intelektualizmu, ponieważ Koreańczycy rodzą się „czyści i bezinteresowni”, W rozdziale II Konstytucji podkreślono jednak, że aby utrzymać rewolucję kulturalną państwo zachęca wszystkich obywateli do aktywnego udziału w budowie socjalistycznego, komunistycznego ustroju, wyposaża lud w głęboką znajomość

17 www.krld.pl/krld/biblio/kimdzongil/krldniezniszczalne.pdf, (dostęp: 24.04.2012).

18 B. R. Myers, Najczystsza rasa. Propaganda Korei Pótnocnej, Warszawa 2011, s. 66. 
natury i społeczeństwa oraz wysoki poziom kultury i technologii, te czynniki mają wpływać na dynamiczny rozwój intelektualny społeczeństwa.

KRLD chroni swoje narodowe dziedzictwo kulturalne, ponadto dąży do budowy „niezłomnych rewolucjonistów”, kompetentnych moralnie i fizycznie zdrowych, którzy będą walczyć dla społeczeństwa i narodu.

Funkcjonowanie społeczeństwa w takim systemie nie byłoby możliwe bez jego pełnej izolacji. Koreańczycy posiadają ograniczone możliwości pozyskiwania informacji i kontaktów z otoczeniem zewnętrznym ${ }^{19}$. Nawiązanie relacji z osobami „z zewnątrz” jest sprowadzone do niezbędnego minimum i ten przywilej posiadają jedynie dyplomaci, handlowcy i niewielka liczba dziennikarzy. Serwisy informacyjne radia i telewizji są starannie przygotowywane i nastawione wyłącznie na przekazywanie informacji, które uprzednio zaaprobowała koreańska elita rządząca i świadomie je ujawnia. Przeciętny obywatel nie ma dostępu do informacji odbiegających od oficjalnej ideologii lub poddających ją krytyce. Wszystkie telewizory i radia, wyprodukowane w KRL-D są tak skonstruowane, by nie mogły odbierać żadnych audycji z Południa, natomiast u posiadaczy zagranicznych urządzeń, programy obce są zagłuszane i ich odbiór jest niemożliwy. Czytanie prasy zagranicznej jest zabronione. Literatura obca jest nieobecna, a przywóz „obcych” książek, plakatów, kaset

\footnotetext{
${ }^{19}$ www.mongabay.com/reference/country_studies/northkorea/SOCIETY.html.
} 
etc., nawet wyprodukowanych w krajach komunistycznych jest surowo zabroniony i podlega karze.

Obywatele Korei Północnej nie mogą również swobodnie podróżować, nawet w obrębie własnego kraju, podobnie jak turyści zagraniczni. Mieszkańcy KRL-D, którzy z racji pełnionych obowiązków, wyjeżdżają do innych państw, po powrocie do kraju zostają zobligowani partyjną przysięgą do zachowania pełnej tajemnicy i dyskrecji o tym, co widzieli i słyszeli na zewnątrz. Oficjalne gazety północnokoreańskie nie są swobodnie sprzedawane, ale w całości rozprowadzane $\mathrm{w}$ specjalnie zaadresowanej prenumeracie. Istnieje zwyczaj, że ta sama osoba nie prenumeruje kilku gazet, lecz wyłącznie jeden organ, co zdecydowanie zmniejsza możliwość dostępu do informacji niezwiązanych z przynależnością do danej organizacji, grupy społecznej itp. Głównym narzędziem propagandowym jest 6-stronicowe wydanie organu KC Partii Pracy Korei, dziennika „Rodong Sinmun”, który w tej wersji rozprowadzany jest wyłącznie w stolicy państwa, a na prowincję dociera 4-stronicowa wersja pozbawiona, ubogiego w informacje, działu zagranicznego.

Hermetycznie zamknięte społeczeństwo, nie znające osiągnięć współczesnej cywilizacji, poniosło widoczne szkody intelektualne. Zainteresowanie ruchów totalitarnych „naukowymi” dowodami znika z chwilą ich dojścia do władzy, wyklucza się wszelki edukacyjny postęp 20 .

${ }^{20}$ H. Arendt, Korzenie totalitaryzmu, Warszawa 2008, t. 2, s. 81. 
Koreański model kształcenia i rozwoju jednostki zakłada jej bezwarunkowe uczestnictwo w życiu społecznopolitycznym. Jak zostało podkreślone na stronach ambasady Korei: „Każdy z nas, kim by nie był, w równym stopniu posiada prawo władzy i uczestniczy w zarządzaniu państwem oraz będąc członkiem jakiejś organizacji politycznej prowadzi pełnowartościowe życie polityczne. W naszym kraju państwo z pełnq odpowiedzialnościq podchodzi do życia mieszkańców. System bezpłatnego kształcenia, system bezpłatnej obsługi medycznej $i$ szereg innych środków realizowanych $w$ interesie ludu, daje wszystkim ludziom możliwość swobodnej nauki, dobrego zdrowia, prowadzić rewolucyjne, pełne romantyzmu, emocjonalnokulturalne życie"21.

Tworzenie od podstaw „nowego człowieka typu dżucze” rozpoczyna się w szóstym roku życia. Dzieci, powszechnie i obowiązkowo posyłane są wtedy do przedszkoli, które usytuowane są w pobliżu zakładów pracy lub należą do nich organizacyjnie. Według norm północnokoreańskich rodzice zostawiają tam swoje pociechy $w$ poniedziałek, a odbierają w sobotnie popołudnie. Od najmłodszych lat społeczeństwo podlega całkowitej indoktrynacji, która zdecydowanie odbiega od świadomego procesu edukacji obywatelskiej. Przedszkole jest pierwszym etapem kształtowania myśli i rozwoju mas. Zajęcia ideologiczne stanowią tam ok. 40\% całego czasu przeznaczonego na proces dydaktyczno-wychowawczy. Nauczyciele zobligowani są do wpojenia młodemu pokoleniu

${ }^{21}$ www.krld.pl/krld/biblio/kimdzongil/zachowac.pdf. 
informacji „z życia i działalności rewolucyjnej towarzysza Kim Ir Sena". W tym celu w placówkach znajdują się odpowiednie makiety, rekwizyty obrazujące najistotniejsze fakty dotyczące życia Wodza, a dzieci są regularnie odpytywane z przyswojonej wiedzy. „Nauka” obejmuje również wychowanie w duchu kolektywizmu i hierarchii, poprzez przypisanie każdego uczestnika zajęć, w ramach powszechnego ruchu „czynów pożytecznych”, do jednej z licznych struktur „gwardii sanitarnej”, „gwardii porządkowej”, „gwardii zazieleniającej” itp. Indywidualizm jest ostro zwalczany. Stałym elementem indoktrynacji jest wychowanie podopiecznych w duchu antyimperialistycznym i antyamerykańskim.

Przedszkolna propaganda oparta jest na gigantycznej mistyfikacji. Dzieci uczą się odpowiednio spreparowanego życiorysu Wodza, nieprawdziwej historii rewolucji i narodu oraz chłoną fałszywe informacje dotyczące obrazu politycznej rzeczywistości. Gdy mają 7 lat ich nauka zostaje rozszerzona o dodatkowy element, jakim jest studiowanie polityki partii i dzieł „Drogiego Przywódcy” oraz Kim Dzong Ila. Następnie między siódmym a ósmym rokiem życia trwa okres przygotowujący do wstąpienia wszystkich dzieci do pierwszej organizacji politycznej „Związku Dziecięcego”, w członkostwo trwa do 15 roku życia.

Organizacja uzupełnia i rozszerza wiedzę ideologiczną uzyskaną w szkole. Każdy przedmiot przesiąknięty jest ideą dżucze. Na lekcjach matematyki uczniowie dodają i odejmują na przykładzie zabitych żołnierzy amerykańskich, a podczas 
nauki języków pracuje się wyłącznie na tekstach zideologizowanych ${ }^{22}$.

W 16. roku życia młodzież obowiązkowo wstępuje do „Socjalistycznego Związku Młodzieży Pracującej Korei”. Jest to zaplecze młodzieżowe partii, z którego wyłonią się przyszłe kadry. W tym wieku młody człowiek jest zalewany masą ideologicznych informacji, które zapewniają kontynuację indoktrynacji. Po ukończeniu 30 lat najbardziej zaangażowane i wyrobione politycznie jednostki wstępują w szeregi partii. Pozostali obowiązkowo zasilają organizację związkową. Jest to zgodne z politycznym wymogiem, by każdy obywatel należał do którejś z wielu organizacji społeczno-politycznych działających pod kierownictwem komunistycznej partii.

Partia Pracy Korei jest ostatnim etapem kariery politycznej, chociaż osiągniecie w niej członkostwa nie jest procesem łatwym. Wystąpienie z partii jest niemożliwe, a wydalenie oznacza wyrok śmierci. Organizacja pozostaje w nierozerwalnym związku z Wodzem. Jak podkreślał Kim Dzong Il, „Kierownictwo partii to kierownictwo wodza [...]. Ponieważ wódz jest wodzem partii, przeto nie można wyobrazić sobie partii i wodza w oddzieleniu [...]. Nazywamy swego wodza ojcem-wodzem, a partie matka-partią dlatego, że organizacje partyjne $z$ wodzem na czele stanowiq podstawę naszego życia społeczno politycznego"23. Partia zorganizowana jest w opar-

\footnotetext{
${ }^{22}$ W. J. Dziak, A. M. Faliński, W kraju Orwella. Uwagi o funkcjonowaniu północnokoreańskiego państwa totalitarnego, b.m.w., b.r.w.

${ }^{23}$ Kim Dzong Il, Trwale ustanowić oparte na dżucze poglądy na rewolucję, Phenian 1989, s. 8.
} 


\section{2 | Olga Kawczyńska}

ciu o struktury wojskowe. Występuje system wodzowski, hierarchia, dyscyplina. Wszystkie zlecone zadania należy wykonywać bezwarunkowo, entuzjastycznie i do końca. „Każdy, kto nie wykona zadania postawionego przez partię, nie ma prawa nawet umrzeć" 24 . Ona też jest inicjatorem wszystkich przedsięwzięć propagandowo-ideologicznych. Zgodnie z tym założeniem raz w tygodniu wszyscy członkowie zobligowani są do uczestnictwa w zebraniach na temat aktualnych problemów politycznych. W każdą sobotę, przed południem, kadry partyjne w terenie otrzymują najnowsze wytyczne komitetu centralnego na najbliższy tydzień i szczegółowo je analizują. W każdą niedzielę wszyscy obywatele studiują dzieła Kim Ir Sena (40 tomów). Podstawowe organizacje partyjne nadzorują, by zgodnie z instrukcją każdy członek partii poświęcił dwie godziny dziennie na samokształcenie ideologiczne, natomiast wyższe kadry raz do roku przechodzą specjalny, 20-dniowy, kurs szkoleniowy 25 .

Zmasowana indoktrynacja odbywa się w pięciu opracowanych blokach tematycznych: wychowanie na ideach dżucze, wychowanie klasowe, wychowanie na polityce partii, wychowanie na rewolucyjnych tradycjach, wychowanie w duchu socjalistycznego patriotyzmu. Każda z tych form ma na celu „trwałe uzbrojenie ludzi w idee dżucze”26, czyli zapoznanie wszystkich obywateli z linią i polityką partii oraz

\footnotetext{
${ }^{24}$ Kim Ir Sen, Historyczne doświadczenia budownictwa Partii Pracy Kore$i$, Warszawa 1987, s. 127.

${ }^{25}$ www.krld.pl/krld/biblio/kimdzongil/dzuczesamoistna.pdf.

${ }^{26}$ Kim Dzong Il, 0 ideach dżucze naszej partii, Phenian 1988, s. 124.
} 
stworzenie wiernej grupy ludzi, podążających za rewolucyjną ideą reżimu. Istotną rolę $\mathrm{w}$ budowie nowej tożsamości odgrywają obowiązkowe imprezy masowe, powszechne manifestacje ludności, defilady wojska i młodzieży, zbiorowe „śluby wierności” i „sztafety lojalności”. Te ostatnie odbywają się 15 kwietnia, w dniu urodzin Wodza, w Pjongjang. Specjalnie dobrane kolumny żołnierzy, chłopów, robotników, inteligencji, młodzieży i dzieci zbierają się na stadionie imienia Kim Ir Sena, obiecując mu wierność, w obecności 100 tys. wyselekcjonowanych słuchaczy. Cały spektakl jest starannie przygotowany i doskonale wpisuje się w ramy indoktrynacji, jaką ordynują społeczeństwu władze Korei Północnej.

Widoczne są również wyraźne tendencje do sprawowania totalnej kontroli społecznej, a w praktyce żadne wydarzenie nie odbędzie się bez wiedzy czy aprobaty władz. W państwie nie istnieją dysydenci polityczni, propagujący jakąkolwiek niezależną myśl. Życie publiczne i prywatne obywatela jest ściśle i precyzyjnie określone przez szereg regulaminów, rozporządzeń, nakazów i zakazów, którym musi się podporządkować. Kontrolę nad 22-milionowym krajem sprawuje milionowa armia oraz dwie potężne organizacje paramilitarne: Robotniczo-Chłopskie Czerwone Pospolite Ruszenie i Czerwona Gwardia Młodzieżowa, w których regularne szkolenie bojowe odbywa $7 \mathrm{mln}$ obywateli. Ponadto strukturę uzupełnia 3-milionowa rzesza członków milicji ludowej, służby bezpieczeństwa i ich rezerwy.

Specjaliści od propagandy i dyscypliny organizują różnego rodzaju zajęcia pozalekcyjne, aby zagospodarować każ- 


\section{4 | Olga Kawczyńska}

dą wolną chwilę młodego człowieka. Indoktrynacja odbywa się również za pomocą ogromnej ilości muzeów, pomników, monumentów, tablic, izb pamięci etc. Wszystkie te symbole mają na celu ujednolicenie rytmu życia ludu, poprzez wspólne prace: sadzenie kwiatów, strzyżenie trawy, cotygodniowe mycie pomników. Zalecany i kontrolowany scenariusz dnia jest dla każdego obywatela identyczny. 8 godzin pracy, 8 godzin snu i 8 godzin pracy społecznie użytecznej. Organizacje partyjne i służby specjalne ingerują w najbardziej prywatne sfery ludzkiego życia. Kojarzą młode pary, sugerują wybór zawodu, miejsce pracy i zamieszkania. Państwo wyposaża obywatela we wszelkie niezbędne rzeczy od najmłodszych lat aż po studia, ofiarowuje również mieszkanie z kompletnym wyposażeniem, łącznie z obowiązkowym portretem „Wielkiego Wodza" i Kim Dzong Ila. Państwo-partia całkowicie przejmuje kontrolę nad życiem jednostki, wkomponowując ją w ramy idealnego ustroju. Jest to „monolityczne wkomponowanie obywatela w żywy krwioobieg polityczny państwa"27.

Mieszkańcom prowincji wolno odwiedzać krewnych w stolicy wyłącznie raz do roku, za uzyskaniem wcześniejszego pisemnego pozwolenia. Uzbrojone posterunki policji i służby bezpieczeństwa kontrolują wszystkie drogi dojazdowe do większych miast, a patrole wojskowe zatrzymują przechodniów na ulicy. Na każdym podwórzu dyżuruje pracownik służby bezpieczeństwa, a klatki schodowe mają swojego dozorcę, współdziałającego z policją polityczną.

${ }^{27}$ Radio Phenian, audycja z 14 września 1982 r., cyt. za.: www.krld.pl. 
Wszystkie wizyty dyplomatyczne, możliwość odwiedzenia zwykłego Koreańczyka w mieszkaniu są całkowicie wyreżyserowane. Gospodarz zostaje uprzednio wyposażony w dobra konsumpcyjne i materialne oraz odpowiednio przeszkolony ideologicznie. Otrzymuje szczegółowy zestaw pytań i wszelkie wytyczne dotyczące rozmowy z obcokrajowcem.

O skali ograniczeń świadczy fakt, iż mieszkańcy nie spacerują po ulicach, dzieci nie korzystają z placów zabaw, a poruszanie się rowerem jest surowo zakazane i traktowane jako niedopuszczalne wykroczenie. Nawet racjonowanie żywności jest determinowane nie tylko przez kryzys, ale również czynniki ideologiczne. Ograniczenie dostaw żywności, sprzyja entuzjazmowi obywateli do dynastii Kimów, która w dniu urodzin „Wiecznego Prezydenta” i Kim Dzong Ila, tj. odpowiednio 15 kwietnia i 18 lutego, obdarowuje poddanych dodatkową porcją zapasów m. in.: 300 gr ryżu, litrem oleju i trzema butelkami piwa. Niedobór konsumpcyjny tłumaczony jest wyższymi racjami społecznymi, głównie sprawami bezpieczeństwa i obronnością kraju, gdyż z przekonania Kim Ir Sena wynika, że każda nieznaczna poprawa warunków materialnej egzystencji ludności, zrodzi konsumpcyjny egoizm i partykularyzm, co zagrozi „ideologicznej czystości szeregów i podważy rewolucyjnego ducha narodu.

Co charakterystyczne, mimo propagowania takiego stylu życia, Konstytucja Korei gwarantuje szereg praw. Prawa i obowiązki opierają się na kolektywistycznej zasadzie „jeden za wszystkich, wszyscy za jednego”. Państwo zapewnia teoretycznie szeroki wachlarz demokratycznych wartości, a także 
materialny i kulturalny dobrobyt społeczeństwa. Teoretycznie obywatele mają równe prawa we wszystkich sferach życia i działalności publicznej. Osoby, które ukończyły 17. rok życia mają czynne i bierne prawo wyborcze do organów administracji państwowej, bez względu na płeć, rasę, przynależność partyjną, zawód, etc. chyba, że na mocy decyzji sądowej zostali pozbawieni praw. Formalnie występuje pluralizm polityczny, prawo do zgromadzeń, wolności słowa i druku, a także demonstracji i strajków. Obywatele mają prawo do wolności przekonań religijnych, składania skarg i wniosków, pracy, wypoczynku, bezpłatnej opieki medycznej, edukacji, rozwoju intelektualnego, swobodnego podróżowania i zmiany miejsca zamieszkania, równouprawnienia. Państwo gwarantuje także nietykalność osobistą i poszanowanie prywatności, a także azyl dla cudzoziemców walczących o pokój, niepodległość lub socjalizm. Obywatel ma obowiązek zabezpieczać polityczną i ideologiczną jedność narodu poprzez ofiarną pracę na rzecz dobra wspólnego, przestrzegać prawa państwa i socjalistycznych standardów życia, bronić honoru i godności mieszkańców KRL-D, poddać się dyscyplinie pracy, bronić i walczyć o wolność kraju, co jest największym zaszczytem dla jednost$\mathrm{ki}^{28}$.

Zapisy konstytucji pokazują, jak znacząco w państwie totalitarnym różni się litera prawa od praktyki politycznej. Społeczeństwo północnokoreańskie nie podejmuje jednak żadnych starań o zmianę tej sytuacji. Poddane kontroli, indok-

${ }^{28}$ www1.korea-np.co.jp/pk/061st_issue/98091708.htm. 
trynacji i izolacji nie jest w stanie wygenerować ruchów opozycyjnych. Represje wobec wszelkich przejawów odmiennego myślenia trwają w Korei Północnej nieustannie od 1945 r. ${ }^{29}$ Propaganda to najważniejsze narzędzie totalitaryzmu w kontaktach ze światem zewnętrznym, ale terror to istota totalitarnej formy reżimu ${ }^{30}$. Elity rządzące, także obecne, związane z Kim Dzong Unem, traktowały tego typu działania jako podstawowe narzędzie umocnienia nowej władzy, ważny element motywujący społeczną przebudowę, argumentując użycie drastycznych metod, próbą ochrony narodu przed trwałym zagrożeniem wewnętrznym i zewnętrznym państwa.

Kim Ir Sen był zwolennikiem i propagatorem represji prewencyjnej i rotacyjnej. Model ten zakłada, że wszyscy obywatele, także najwyżsi przedstawiciele władzy, trzymani są w atmosferze niepewności, strachu i obawy co do swych dalszych losów, które mogą skończyć się pobytem w więzieniu, torturami, śmiercią, czy odosobnieniem i samotnością. Donosicielstwo jest traktowane $\mathrm{z}$ najwyższym szacunkiem, jako wyraz rewolucyjnej czujności i prawnie usankcjonowany obowiązek obywatela.

Kara śmierci grozi każdemu obywatelowi, który świadomie bądź nie „rozpowszechnia reakcyjne poglądy”, „czyni uwagi o reakcyjnej treści”, „manipuluje informacjami”, „szerzy pogłoski” lub „napisze choćby kilka słów o treści kontrrewo-

\footnotetext{
${ }^{29}$ www.northkorea.pl/index.php/2011/04/12/usa-raport-dotyczacypraw-czlowieka-w-korei-polnocnej-i-poludniowej/, (dostęp: 20.05.2012).

${ }^{30}$ H. Arendt, op. cit., s. 79.
} 
lucyjnej"31. Podobna kara grozi za próbę ucieczki na teren obcej ambasady, za granicę lub posiadanie drukowanych materiałów o treści reakcyjnej.

Liczba więźniów politycznych stale oscyluje wokół 1\% obywateli. W 1990 r. władze południowokoreańskie podały, że w 12 obozach koncentracyjnych na terytorium KRL-D, przebywa ok. 152 tys. osób, skazanych za przestępstwa polityczne $^{32}$. Są one nie tylko miejscem eksterminacji i poniżenia człowieka, ale mają na celu usunięcie spontaniczności, jako wyrazu ludzkiego, a także przekształcenie osobowości osób, odsiadujących wyrok. Wśród uwięzionych znajdują się również osoby sprawujące ważne funkcje państwowe m.in. trzech byłych premierów - Li Gun Mo, Pak Kum Chul, Hong Song Riong, wiceprezydent Kim Dong Gyu oraz rzesza przywódców partyjnych z terenu, wyższych oficerów, a także dyplomatów, którzy swym niechlubnym zachowaniem narazili na dotkliwe represje siebie oraz całą bliższą i dalszą rodzinę. Osoba, która znalazła się w obozie, niezależnie z jakim wyrokiem, pozostaje tam do śmierci33.

\footnotetext{
${ }^{31}$ W. J. Dziak, A. M. Faliński, op. cit., s. 79.

${ }^{32}$ www.nkdb.org/bbs1/data/publication/Political_Prison_Camp_in_ North_Korea_Today.pdf.

${ }^{33}$ W Korei Północnej wyróżnia się 3 kategorie więzień. Klasyczne, w których kilkunastoletnie wyroki odsiadują zwykli więźniowie; przejściowe, to oddziały stosunkowo najlżejsze, w których znajdują się skazani za drobne przestępstwa oraz więzienia społeczne, do których trafiają najczęściej obywatele bez udowodnionych zarzutów i braku wyroku sądowego, a także nie wykazujący nadmiernej aktywności społecznej. Zob. W. J. Dziak, Kim Ir Sen. Dzieło i polityczne wizje, Warszawa 2000, s. 365.
} 
Istnieją trzy kategorie obozów. Do obozów pracy przymusowej trafiają drobni przestępcy i polityczni dysydenci. W obozach zsyłki umieszczani są nieuczciwi kupcy, rodziny uciekinierów oraz duchowni, natomiast w obozach koncentracyjnych wyrok odsiadują najwięksi wrogowie reżimu i Wodza, którzy wyrażali zdecydowany sprzeciw wobec linii $\mathrm{rządu}^{34}$.

W 1992 r., na podstawie umowy międzypaństwowej, na terenie byłego ZSRR w koreańskich obozach pracy przebywało 22 tys. obywateli Korei Północnej, zesłanych tam przez Kim Ir Sena, jako niewolnicza siła robocza, zatrudniona w syberyjskich lasach przy wyrębie drzewa.

Oficjalnie w KRL-D nie tylko nie ma więźniów politycznych, ale nie istnieje nawet instytucja więzienia. To zaś, o czym pisze „burżuazyjna prasa”, to popularne w kraju ośrodki oczyszczające, w których przebywają pospolici więźniowie, reedukowani tam przez pracę. [...] Bardzo często sami przestępcy zgłaszają się tu dobrowolnie na oczyszczającą kurację"35.

Brak demokracji dotyczy także podstaw funkcjonowania koreańskiej gospodarki. W ekonomii idea dżucze podkreśla potrzebę samowystarczalności, która pozwoli zabezpieczyć kraj przed wpływami narodów imperialistycznych [...] zapobiega kryzysowi ekonomicznemu i zagranicznym wpływom - umożliwia to wyeliminowanie różnic klasowych i roz-

\footnotetext{
${ }^{34}$ Ibidem, s. 365-366.

35 Ibidem, s. 70.
} 
kwit narodu"36. Zapisy te wskazują na czerpanie z idei komunizmu.

System Korei Północnej opiera się na gospodarce centralnie planowanej37. Charakteryzuje ją dominacja własności państwowej, opartej na paternalizmie ${ }^{38}$ i biurokratycznej koordynacji bez możliwości przejawiania inicjatywy indywidualnej. Ponadto kluczowa jest ilość, a nie jakość wyrobów. Społeczeństwo poddane jest całkowitej kontroli ekonomicznej, przejawiającej się m. in. zaopatrzeniem przez państwo we wszystkie artykuły żywnościowe oraz artykuły pierwszej potrzeby za symboliczną opłatą, przy czym dostęp obywateli do podstawowych świadczeń i dóbr opiera się na klasyfikacji obejmującej 3 rangi i 51 kategorii ${ }^{39}$. Trudności w zdobyciu elementarnych świadczeń nie dotyczą elity, tj. wyższej kadry, której liczebność szacuje się na ok. 50 tys. osób.

Ceny nie są powiązane z popytem lub kosztami produkcji i są arbitralnie ustalane w trzech grupach. Opierają się na

36 www.krld.pl/krld/biblio/kimdzongil/dzuczesamoistna.pdf, (dostęp: 15.03.2013).

${ }^{37}$ Cechy gospodarki centralnie planowanej:

a) Społeczna własność środków produkcji;

b) Centralne planowanie;

c) Gospodarka niedoborów;

d) Brak mechanizmów opartych na podaży i popycie.

38 Paternalizm - doktryna ekonomiczna i społeczno-polityczna, w myśl której jednostki (obywatele, społeczeństwa, a nawet całe narody) nie są w stanie kierować swoimi sprawami w obiektywnie dobry dla nich sposób i w związku z tym potrzebują pomocy i kontroli innych jednostek (grup), które są predestynowane lub przynajmniej posiadają nabyte kompetencje do sprawowania tej funkcji.

${ }^{39}$ W. J. Dziak, A. M. Faliński, op. cit. 
hierarchii użytkowników: najniższe dla firm państwowych, średnie dla spółdzielni i detaliczne, dla rynków chłopskich.

System cechują kampanie ideologiczne, sztucznie i pod przymusem stymulujące wzrost wydajności a także zatrudnienie ze względów społecznych i politycznych, co wpływa na niedobór siły roboczej w innych branżach.

Konstytucja głosi, że Korea Północna opiera się na zasadzie socjalistycznych stosunków produkcji i fundamencie niezależnej gospodarki narodowej. Środki produkcji są własnością państwa i społecznych organizacji spółdzielczych. Własność Skarbu Państwa, w skład której wchodzą wszystkie zasoby naturalne kraju, koleje, transport lotniczy, usługi, zakłady komunikacyjne, jak również fabryki, przedsiębiorstwa, porty i banki należą także do całego narodu. Własność spółdzielni społecznych jest w posiadaniu wyłącznie osób pracujących, zaangażowanych w działanie organizacji.

Brak podatków determinuje wzrost zamożności materialnej społeczeństwa, jedynym warunkiem uzyskania od państwa żywności, odzieży i mieszkań jest praca. Jak przekonuje partia, „głównym celem jest uzyskanie wysoko rozwiniętej gospodarki narodowej, w oparciu o rewolucję techniczną, która uwolni ludzi od trudu i zmęczenia, po 8-godzinnym dniu pracy, optymalnie wykorzystanym przez właściwą organizację i egzekwowanie dyscypliny w zakładzie. Państwo wspiera rozwój i dąży do zniwelowania różnic między miastem a wsią. Minimalny wiek do podjęcia pracy to 16 lat".

Gospodarka KRL-D opiera się na wieloletnich planach. Państwo opracowuje i wdraża ich szczegółowe zapisy tak, aby 
utrzymać prawidłowe saldo akumulacji ${ }^{40} \mathrm{i}$ konsumpcji, a także zapewnić wzrost dobrobytu ludności. W związku z planami rząd KRL-D sporządza budżet państwa i nadzoruje jego wykonanie. W celu pozyskania zagranicznego kapitału, władze zachęcają do inwestowania w specjalnych strefach ekonomicznych, przy jednoczesnej realizacji polityki taryfowej, aby ochronić gospodarkę narodową41.

Dążenie do samowystarczalności, oparte na ideologii stworzonej przez Kim Ir Sena, powoduje izolację, która znacznie osłabia wydajność i prowadzi do uzależnienia od pomocy zagranicznej, niezbędnej dla przetrwania społeczeństwa i funkcjonowania gospodarki.

Decyzje, które w krajach gospodarki rynkowej podejmuje zarząd firmy lub indywidualny wytwórca, w Korei Północnej zapadają w elitarnym kręgu władzy centralnej, przez co uwzględniają ideologicznie umotywowane utrzymanie władzy, negatywne podejście do obcego kapitału, eksploatującego koreańską klasę robotniczą, nieufność wobec Zachodu, oraz unikanie samodzielnych inicjatyw, dlatego odrzuca się stosowanie nowoczesnych rozwiązań produkcyjnych czy organizacyjnych $^{42}$.

Reżim północnokoreański podejmuje działania sprzeczne z zapisami ustawy zasadniczej. Mimo demokra-

\footnotetext{
${ }^{40}$ Akumulacja- przeznaczenie części dochodu narodowego na inwestycje oraz na zwiększenie zasobów środków obrotowych i rezerw. ${ }^{41}$ www1.korea-np.co.jp/pk/061st_issue/98091708.htm\#Chapter2: Economy. ${ }^{42}$ www.krld.pl/krld/biblio/kimirsen/oosiagnieciu.pdf, (dostęp: 15.03.2013).
} 
tycznych uregulowań i utopijnej koncepcji rozwoju jednostki, w ramach narodu, społeczeństwo ulega całkowitej indoktrynacji, propagandzie i izolacji. Każdy obywatel pełni określoną rolę $\mathrm{w}$ państwie i nie ma możliwości awansu w hierarchii, a przejawy niezadowolenia, opozycji wobec władz są sankcjonowane i podlegają surowym karom.

Można wyodrębnić wiele czynników warunkujących brak podstaw demokracji w Korei. Izolacja społeczeństwa, łamanie praw człowieka i życie obywateli poniżej granicy ubóstwa, brak wolności a także pluralizmu politycznego, centralizacja wyrażana poprzez dominację Partii Pracy Korei, wzmożona indoktrynacja, atomizacja społeczeństwa, szerzenie terroru oraz stosowanie represji wobec decydentów. Reżim KRL-D jest przykładem państwa totalitarnego, w którym prawa jednostki i jej potrzeby są wtórne do potrzeb partii i państwa.

Tak silna ideologizacja systemu jest jednym z podstawowych determinantów kryzysu w sferze politycznej, społecznej i gospodarczej. Uniemożliwia ona bowiem zaistnienie pluralizmu, demokratyzację systemu, reformy społecznogospodarcze oraz wyjście z izolacji.

Obecnie nie ma perspektyw na zmiany czy reformy systemu Koreańskiej Republiki Ludowo-Demokratycznej. Możliwość taka pojawiłaby się dopiero w momencie odsunięcia od władzy rodziny Kimów, co w obecnych warunkach nie jest możliwe. 